Paper for DISCOURSE AND SOCIETY

\title{
Common-sense anti-racism in book group talk: The role of reported speech (v2: 11/1/12)
}

\section{Corresponding Author:}

\section{Bethan Benwell}

University of Stirling

\section{Address:}

English Studies

Division of Literature and Languages

School of Arts and Humanities

University of Stirling

Stirling FK9 4LA

United Kingdom

b.m.benwell@stir.ac.uk

Tel: $\quad 01786467976$

Fax: 01786466210

SHORT TITLE: Common-sense anti-racism in book group talk

Words: 8035

Bytes: 120KB 


\section{Biographical note}

Bethan Benwell is a Senior Lecturer in Language and Linguistics at the University of Stirling. She has published chapters and articles on discursive approaches to reading and reception, discourses and representations of masculinity in popular culture, and (with Elizabeth Stokoe, Loughborough University) on tutorial discourse and student identity. She is the editor of Masculinity and Men's Lifestyle Magazines (2003, Blackwell), coauthor (with Elizabeth Stokoe) of Discourse and Identity (2006, EUP), co-editor (with James Procter and Gemma Robinson) of Postcolonial Audiences: Readers, Viewers and Reception (2012, Routledge) and of a Special Issue of New Formations (73) 'Reading After Empire' (2011). She was co-investigator (with Kay, Procter and Robinson) on an AHRC-funded project (2007-2010) examining the relationship between readers, location and diaspora literature: http://www.devolvingdiasporas.com/ 


\title{
Common-sense anti-racism in book group talk: The role of reported speech [submission to Discourse and Society]
}

\begin{abstract}
This paper explores the rhetorical accomplishment by British book group members of anti-racist identities through their discussions of fictional texts exploring themes of race and immigration. What I am terming 'common-sense anti-racism' is a social action or stance that is presented as self-evidently taken by speakers (and assumed to be shared by other participants), yet explicitly flagged at the same time. Speakers in book group discussions routinely display enlightened, anti-racist views principally by invoking the figure of the 'racist other' and their reported speech. Reported speech has been argued to possess evaluative or 'editorializing' functions in talk (Buttny 1997; Holt 2000), specifically by 'ascribing words to out-group members as a way to criticize their actions' (Buttny 2003: 107). Moreover, many of the analysed examples of reported speech do not involve explicit markers of quotation or shifts in footing, meaning that the attribution of certain words (and their accompanying values) have to be disambiguated by hearers assumed to share the same views on race and racism. The implicit status of the reported speech here does important identity work in consolidating the values of the group and strengthening its membership.
\end{abstract}


Adopting a broadly ethnomethodological approach, the paper also focuses on the rhetorical work done by the 'common-sense' presentation of anti-racism, its active orientation to the consensus of the group and arguably defensive 'warding off' of potential assumptions about the disposition or stance of the speaker in discussions of race and racism. It questions why anti-racism tends to be packaged as an accountable matter in need of some impression management in the way that racism often is, and concludes that this is linked to the way in which it operates in contexts where anxieties around issues of race and racism continue to exist.

\section{Keywords}

common sense, anti-racism, book group talk, reported speech, the racist 'other', discourse analysis, ethnomethodology. 


\section{Common-sense anti-racism in book group talk: The role of reported speech}

This paper emerges out of a three-year AHRC-funded project investigating the relationship between reading, location and migration ${ }^{1}$. Analysing a series of transcribed book group discussions across the UK and in parts of Africa, the Caribbean, India and Canada, one of our main aims has been to explore how various readers in different places respond to contemporary narratives of movement, migration and diaspora (see Benwell, Procter and Robinson, 2012). The choice of 'diasporic fiction' as our set texts, describing the lives of immigrant communities in Britain, such as Monica Ali's Brick Lane, Zadie Smith's White Teeth and Andrea Levy's Small Island means that our groups' discussions are clearly situated within a discursive landscape of British immigration, discourses of race, identity and belonging.

\section{Social and moral functions of book groups}

The focus of this particular paper is, however, less upon the issue of literary reception and evaluations of a series of specific texts and their characters, than upon some of the rhetorical, moral and identity work occasioned by the topics of ethnicity, race relations and immigration which tend to emerge in discussions of diasporic fiction in our UK

\footnotetext{
${ }^{1}$ Our project, Devolving Diasporas: was funded by the AHRC between 2007-2010 and involved researchers from Newcastle University (Procter and Kay) and from the University of Stirling (Benwell and Robinson). We recorded approximately 90 hours worth of book group discussions from 16 groups across a number of continents.
} 
contexts. Elizabeth Long's ethnographic study of women's book clubs has commented in detail upon the book group as a site of identity production. Her study focuses particularly on the interface between a reader's own personal experience and a book's value as a realist text through a process of 'self-recognition' (2003: 153). But selfrecognition, of course, is not only an act in and of itself, but also a form of social action and identity work in interaction. When we turn to book group discussions, our corpus of data shows how participants locally manage their own presentation of identity and belief in discussions of race and race relations as morally accountable activities.

The main analytical focus of this paper is the rhetorical accomplishment by British book group members of anti-racist identities through their discussions of fictional texts exploring themes of race and immigration. What I am terming 'commonsense anti-racism' is a social action or stance that is presented as self-evidently taken by speakers, yet explicitly flagged at the same time - what Derek Edwards describes as ‘designed visibility' (Edwards 1997: 99). Speakers appear to need to establish their enlightened anti-racist credentials and dispel any possibility of being deemed racist in discussions of fictional texts that portray racism. This delicate (and sometimes defensive) stance seems to characterise a particular kind of educated, liberal, white, 
western consciousness in relation to issues of immigration ${ }^{2}$, particularly in a British context ${ }^{3}$.

\section{Common Sense}

Common sense is defined by the New Shorter OED as '[g]ood sound practical sense in everyday matters' and ' $[\mathrm{t}]$ he faculty by which certain beliefs are generally accepted without philosophical enquiry’ (1993: 454). Garfinkel describes common-sense knowledge thus: 'socially sanctioned grounds of inference and action that people use in everyday life, and which they assume that other members of the group use in the same way' (1956: 185). Thus 'common sense' is already owned, collectively and consensually held and is a form of knowledge or stance that does not require evidence, research or justification: it is 'ordinary' and 'untutored' (OED online, 2011). For this reason it has great ideological potential: when propositions are rhetorically packaged as 'reasonable' or 'commonsensical', any ideological or biased underpinnings are rendered invisible, and possible alternatives are omitted from the discussion. In this way, common sense is not merely a category or repository of knowledge, but also operates as a type of reasoning, justification or accounting in its own right. It is a form of rhetoric

\footnotetext{
${ }^{2}$ Gilroy ( 1987: 117) observes that anti-racist movements in the UK have been largely directed and promoted by whites acting in the interests of race relations.

${ }^{3}$ Research in other national contexts, particularly Australia and New Zealand, suggests that racist discourses (particularly those directed towards Indigenous populations) are arguably more prevalent and tolerated, and thus constraints on voicing anti-racist sentiments exist, e.g. Mitchell, Every and Ranzijn 2011; Van den Berg, Wetherell and Houtkoop-Steenstra 2003; Wetherell and Potter 1992.
} 
that is invoked to support a particular view or argument, to naturalise ideological positions, and crucially to suppress debate.

Common-sense reasoning and its functions have been discussed by a number of writers working within the fields of Social and Discursive Psychology and Ethnomethodology - disciplines in which the 'exposure' of commonsense is in many ways central to the analytical enterprise. 'Common-places' - types of well-established moral aphorisms or maxims (Billig 1996: 21), 'shared knowledge' (Edwards 1997: 255), 'mundane reasoning' (Pollner 1987) ‘mundane common sense' (Edwards 1997: 52), ‘common understandings' (Garfinkel 1967), 'common-sense knowledge’ (McHoul and Watson 1984), 'script formulations': 'how actions and events are described as more or less routine or expectable' (Edwards 1994: 211), 'categorial formulations' (Stokoe 2010; 2012): person category references which intrinsically index some kind of intersubjective agreement about them, e.g. 'that sort of laddish bloke', and 'folk theories' (Edwards 1997: 255), are all standard devices for factual accounting and formulating an assumed consensus in interaction (whether one actually exists or not).

One of the interesting properties of common sense is that it simultaneously dispenses with the need for accounting (i.e. if a position is commonsensical it does not need to be justified - it is inevitable, natural and undeniable), whilst being in and of itself a form of accounting: 
The rhetorical force of this device is that it appears to be invoking self-evident, undeniable, obvious knowledge, while at the same time accomplishing things as so... in a manner that makes denial difficult (Edwards 2007: 256)

The accounting function of common sense is thus, despite its appeal to commonly held beliefs, suggestive of the anticipation of and need to counter a possible 'other view' (Billig 1996) and thus a means of refuting possible counter descriptions.

A variety of discursive forms are associated with the accomplishment or display of common sense in interaction, some of which are rhetorically designed 'to make denial difficult' such as the use of 'extreme case formulations' (Pomerantz 1986), appeals to participant intersubjectivity including elliptical or generalising formulations such as 'y'know' (what Schiffrin 1987: 276 describes as a 'marker of consensual truths') and 'that sort of', general extenders or list completors (Jefferson 1990) such as 'and so on', 'stuff like that', 'etcetera', and, as we shall see shortly, forms of reported speech.

Examples of these discursive forms can be seen in our first example of commonsense anti-racism which shores up the 'taken-for-granted' status of anti-racism within this interactional context:

\section{EXTRACT A}

1 S5 but (0.5) I mean hhh well I suppose I (0.2) I was (drawn up 
(Glasgow WI White Teeth)

In this example the speaker appeals to a shared, 'common-sense', non-racist understanding that the view that ethnicity must map exclusively on to nationality is an inaccurate and ignorant one, and in this way the racist view is 'othered' - 'that stupid thing'. This is also a generalised formulation which appeals to shared knowledge about the existence of this familiar, repeated form of racism. The recreation of direct reported speech here simultaneously lends empirical support to the observation (such questions plausibly do occur in reality), and functions to signal the negative evaluation of the reported speaker's views (see also Buttny 1997; Buttny and Williams 2000; Holt 2000; Stokoe and Edwards 2007). The functions of reported speech will be elaborated later in the paper.

\section{EXTRACT B}

1 S1 I always find it amazing that people say (.) ooh you know the

$2 \quad>$ sort of classic $<$ they come to our country they should be

3 like $\underline{u}: s(0.8)$ but you know British pe.:ople who go abro:ad are 
(Edinburgh PB White Teeth)

In this second example, the speaker uses extreme case formulations ('always find it amazing'), the generalised second person pronoun in the phrase ' $y$ 'know', and a form of reported speech prefaced by 'the sort of classic' in order to voice a belief which is clichéd, well worn and familiar to listeners.

By contrast, in the following example, we see a display of anti-racism by S6 which is arguably not presented as tacit 'common sense' but expounded explicitly as an opinion and with no evident indication that any of its assumptions are already shared by its listeners:

\section{EXTRACT C}

1 S6 yeah yeah but I think what (0.2) what is imperative f- for all

2 of us is (.) er (0.4) when the that fe:ar is not to let our

3 fear cloud our judgement

4 S5 ah

5 S6 and whenever we deal with people er to give them the benefit

6 of the $\uparrow$ do:ubt

7 S5 yes

8 S6 and a nice young man with a be :ard (.) is (.) maybe just a

$9<$ nice young man $>\uparrow$ with a be: $\operatorname{ard}(0.2)$ and he happens to be 


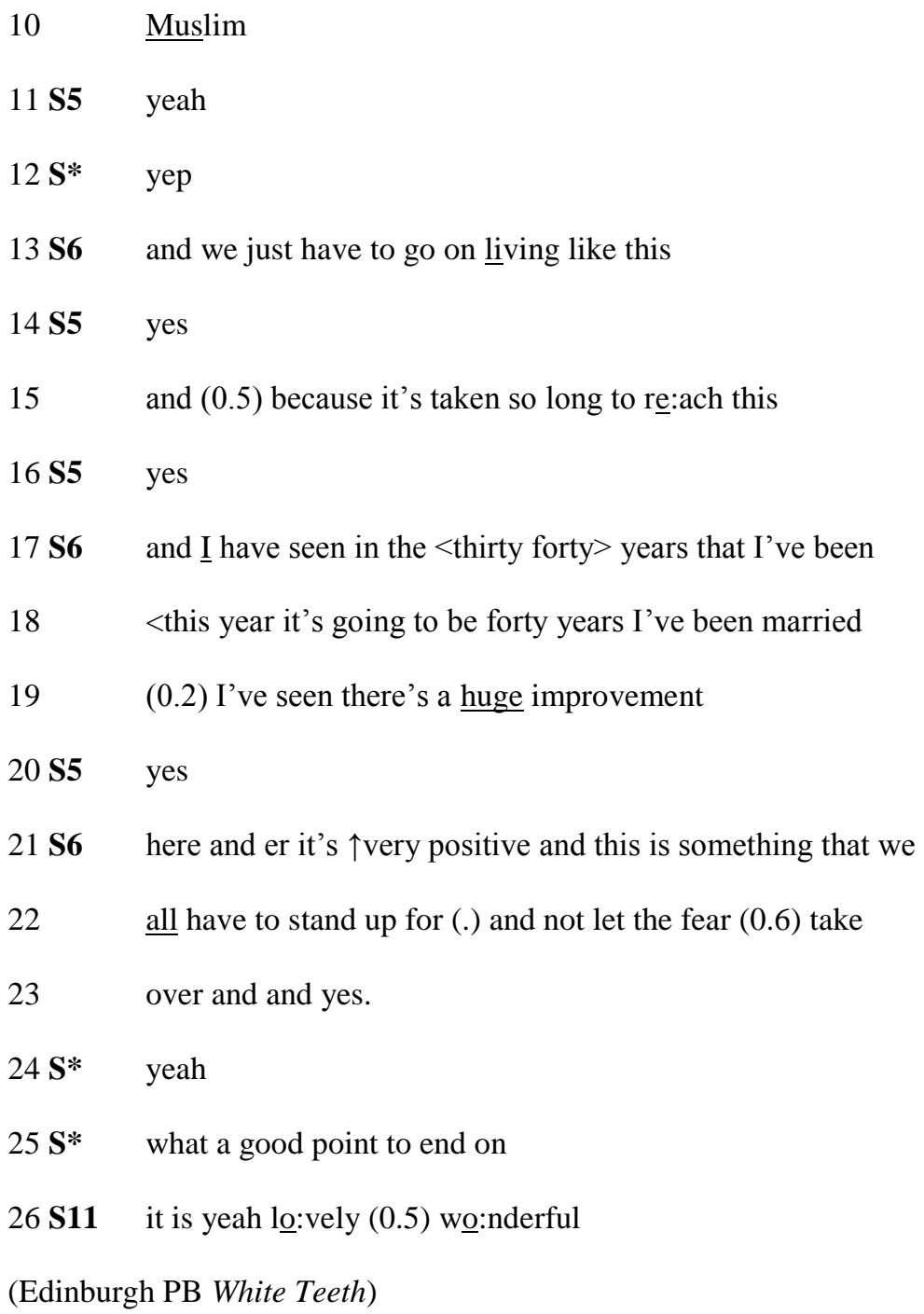

Indeed, the responses of the other members are indicative that this sequence of talk occupies the status of a 'point' (1.25) within a debate. It was precisely the almost unique appearance of this form of persuasive anti-racism within our data that alerted me 
to the fact that anti-racism is much more normatively packaged as a tacit, commonsense notion within the talk of our book group members.

\section{'New Racism' and common sense racial discourse}

And yet, why is it that anti-racism is so uniformly tied to common sense across our data, particularly when common sense has been shown to operate as a way of suppressing dissent? There have been a number of studies into discourse about race which have shown that common sense is a rhetorical manoeuvre which is commonly employed where speakers are keen to distance themselves from any inference that their views might be deemed prejudiced on the basis of race. Most studies of race talk in the past few decades have been oriented to what has been termed 'the new racism', after a study of public discourse about immigration by Martin Barker in 1981. Influential studies of discourse about race and immigration across a range of written and spoken, public and private contexts (Billig, 2001; Bonilla-Silva and Forman 2000; Rapley, 1998; Van den Berg et al, 2003; Van Dijk, 1991, 1992; Wetherell and Potter, 1992) have tended to focus on white speakers or writers and a series of rhetorical strategies which anticipate the view that their beliefs (about e.g. immigration, inequality) are likely to be heard as racist (due to their negative presentation of the qualities or actions of particular ethnic groups), and which thus sets out to deny this, either explicitly or implicitly. These rhetorical strategies are designed to offer reasoned support for views which might be 
deemed racist to avoid the imputation that irrational, race-based prejudice is what motivates them in a social climate where 'common-places of prejudice... have been removed from dialogue, or public thought' (Billig 1996: 217). Van Dijk (1987), for instance, identifies 'examples' (where specific negative instances relating to e.g. an ethnic minority individual are used to offer empirical substantiation for more generally negative views) and 'apparent concessions' (where sympathy or a positive evaluation is initially directed at one aspect of an ethnic minority group's circumstances before a more damning verdict is offered). Barnes, Palmary and Durrheim (2001) in a study looking at mixed race interactions in informal settings observed a series of strategies deployed by white speakers to manage the potential for their views to be read as racist in the company of a mixed race couple: these included humour, personal experience (again drawing on an empiricist register) and imputing racist views to other people. Edwards (2003) observes a range of strategies linked to the accomplishment of common sense in the talk of white New Zealanders discussing race and immigration, such as appeals to intersubjectivity (y'know), vague and generalising formulations, and the description of consistent experiences (linking to the rational, empirical basis for judgements). Buttny (1997), examining the speech of both white and African American students on an American campus observes that reported speech is used by both groups of students as a way of negatively representing others' actions in the context of troublesome racialized events. 
However, we might ask, why does anti-racism need rhetorical work to make it presentable? Why might it also be an accountable matter in need of impression management in the way that racism is? Given the 'powerful norms of anti-racism' (Barnes et al, 2001: 326) that currently exist in our society (and particularly across our book groups, where members are largely educated, middle class and liberal in their politics), why isn't anti-racism either so 'taken for granted' that it is truly invisible, or promoted in an opinionated way as we saw in the isolated example above? The active ‘common-sense' presentation of anti-racism - securing consensus, avoiding debate, whilst at the same time implicitly countering an 'other' view - is suggestive that it operates in contexts where anxieties around issues of race and racism exist.

Interestingly across our corpus of data, we were able to identify a series of rhetorical strategies linked to the accomplishment of common-sense anti-racism which were remarkably consonant with strategies linked to new racism and the denial of prejudice, including generalising formulations, markers of intersubjective agreement and reported speech. Both 'new' racism and anti-racism are arguably mobilised by the same stigma that attaches to the irrationality of racism and the desire to 'dodge the identity of prejudice' (Wetherell and Potter, 1992: 211). Both types of strategy are aimed at achieving membership of the "moral community" of the nonprejudiced' (Barnes, Palmary and Durrheim, 2001: 324), even if the ultimate motives for this differ. The same rhetorical discourses may thus be deployed in pursuit of 
ideologically opposing goals, an observation that has been replicated in research that has examined how the same rhetorical strategies are often used in pursuit of both racist and anti-racist arguments (Fozdar, 2010; Verkuyten, De Jong and Kees Masson, 2002); so, for example, an 'equality' argument may be invoked to both support and refute the principle of affirmative action. As Billig points out, 'the same common-sense [may] be the location of arguments which contradict one another' (1996: 203). Similarly, the rhetorical function of common sense means that it has an inherently argumentative or 'dilemmatic' structure (Billig et al 1988; Billig 1996), meaning that various commonsense discourses may come into conflict with one another in the form of 'contrary commonplaces' (Billig, 1996: 202) (e.g. 'fairness' vs 'empathy') thus shoring up the commonsensical 'rightness' of two opposing ideological positions on race relations.

More generally, the range of research examining what we might broadly term 'race talk' points to a consistent form of impression management which links a range of dispositions to the topic of race to strategies deployed in mitigating inferences of racism. Any topic which invokes the possibility of race discourse (such as immigration, migrant integration, racism) with or without any suggestion of a prejudiced or racist stance, is likely to be handled with great delicacy and with an awareness of the existence of a series of shared discourses and tropes of which co-participants will also be aware. Whitehead (2009), for instance, observes in a study of race training sessions, 
that people orient to what he terms 'racial common sense' while at the same time 'managing how their actions will be understood in the light of it' (329).

We will now turn to an examination of how common-sense anti-racism is commonly accomplished in interaction.

\section{Othering the Racist}

A prevalent strategy for the performance of 'common-sense anti-racism' is the process of 'othering' - the construction of an overtly racist group against which the speaker's values are implicitly contrasted. This has resonances with Richard Buttny's work on the use of reported speech in race talk as a means of constructing a 'portrait of the other' (1997: 480), but where Buttny's 'other' is characterised along ethnic lines (a 'racial other'), our speakers constuct an 'other' which is drawn along ideological ones (the 'racist other'). This process of self identification contextualises readers' responses to a fictional text in which racism is a dominant theme, and by locating speakers ideologically, also performs important identity work within the group itself.

In this short excerpt, participants have been discussing a kind of common-sense racism that is associated with an older generation and frame their response to the racism portrayed in Small Island during the war in terms of their own 'enlightened' and commonsensically non-racist identities. 


\section{EXTRACT D}

1 S1 but I mean $\uparrow$ people (0.4) still behave that way (.) in 1994 we

2 went on holiday to Tenerife and we went to one of these $\uparrow$ shows

3 (0.2) and we were at a table with other British people >they

4 were Welsh< in fact (.) and (.) the Drifters came on and I've

5 never heard of them before (.) and they came on and this man

6 said to us (.) shall we throw bana:nas? (0.2) and we didn’t

$7 \quad$ understand (.) what he me:ant

$8 \mathbf{S} * \quad$ HEh heh heh

9 S1 so he re $\uparrow$ peated it (.)and ex $\uparrow$ plained to uhs

$10 \mathrm{S2}$ heh hh I don't believe that

11 S1 but we left about £twenty minutes later you know £we felt £we

12 can't sit here

$13 \mathbf{S 2}$ well I'm wondering if the Welsh have cha:nged much because

14 there was a conversation that Danny was having with a Welsh

15 (.) man on holiday last year in Corfu: and $<$ he said I can't

16 believe what that man's saying to me it was just (0.2) you

17 know the way he was talking about the Greek folk n (0.2) you

18 know like (.) it's like you think wh- have $\uparrow$ these people got

19 no conception...

(Glasgow WI, Small Island)

Here the 'racist other' identities are gradually reified and closed off by a series of increasingly specific identifiers: firstly the vaguely defined 'people' (line 1), then 
'British people' (line 3) and finally the nationally-specific 'Welsh' (line 4), a group of whom have been making racist jokes about an African American pop group, The Drifters during a holiday in Tenerife. S2 orients to S1's mention of Welsh identity (lines 3-4) - which is packaged by S1 as an incidental observation, but is arguably marked by its mention - and retrospectively endows it with homogeneity by linking this anecdote via a second story (Sacks 1992) to another example of racism her friend or partner, Danny encountered when talking to a Welsh speaker about the Greek community whilst on holiday in Corfu (lines 14-17). This nationally delineated and apparently homogenous identity ('the Welsh' (line 13) and 'these people' (line 18)) allows a clear contrast with the Scottish speakers, enabling them to distance themselves from the racist behaviour described. Reported discourse is used to present both the damning words of the racist 'other' group as well as to provide direct access to the unmediated thoughts of the speaker and her party. The recipients ( $\mathrm{S}^{*}$ and S2) of S1's story assess the reported speech through laughter (lines 8 and 10), making its evaluative function explicit, a move observed by Elizabeth Holt (2000) in her analysis of 'concurrent responses to reported speech'.

Common-sense anti-racism is often constructed by the attribution of racism to an 'other', older generation, who are simultaneously exonerated by the fact of being a product of their historical (and racist) conditions: 


\section{EXTRACT E}

1 S1 I (.) I mean (0.5) my daughters are absolutely appalled and I

2 was I mean $<$ my parents are well educated (.) em peo $\uparrow$ ple (0.2)

3 and my father has worked widely across the wo:rld (.) but he

4 can come out with some things sometimes that y'know

$5 \quad(0.2)$ leaves me absolutely breathless and (0.2) totally appals

6 his $\uparrow$ grandchildren [.hhhh] $\uparrow \uparrow \underline{w h y}$ does he s- ! and he doesn’t

$7 \quad$ actually if you pull him u:p

8 S2 uhuh

9 S1 he's horrified at the thought that anybody would think he was

$10 \quad \uparrow$ like that but it's just common (0.4) $\uparrow$ parlance to him

(Glasgow, WI Small Island)

What is striking here are the accounts provided for the parents' racism. It is neither ignorance, lack of education or a desire to 'be' racist, but a naturalised outlook and way of talking: 'just common parlance to him'. However, despite this ostensible sympathy (reminiscent of Van Dijk's 'apparent concessions' (1987)) for the unwitting nature of her father's racism, the speaker reveals the imperative of distancing her own stance from any possible imputation of racism by the use of extreme case formulations ('leaves me absolutely breathless', 'totally appals', 'horrified'), her moral account of 'pull[ing]

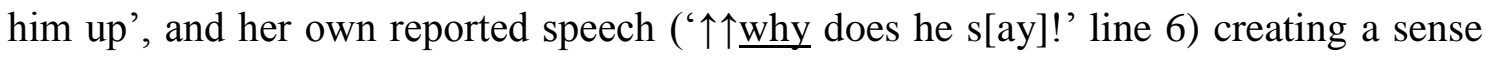
of unmediated access to her original appalled response. A similar pattern of exoneration 
combined with 'othering' can be observed below where the speaker explicitly characterises her parents' racism as such whilst accounting for it as an inevitable, unwitting product of its time (and thus implicitly constructing anti-racism as a product of this time):

\section{EXTRACT F}

1 S1 well of cou- absolutely <but I just (.) I can well I

2 suppose it's things like with my mum and da:d (0.2) I

3 kno:w they kind of want to know (.) cause my mum and

4 dad are very much of the generation that would have

5 recei:ved the people of the (.) on the Wịndrush

6 really (0.4) and are prejudiced without (.) y'know

7 without even having a $\uparrow$ clue to the point that

8 S2 even knowing it

9 S1 $\mathrm{mmm}(0.2$.) they say things like $\uparrow I ' m$ not raciali:st

10 we're not racialist $\uparrow$ here

11 Grp Heh heh heh

(Nottingham WT/SI)

Again, reported speech prefaced by generalising particles ('they say things like') is deployed to register disapproval for the views of the unintentionally racist parents. As we saw in extract $\mathrm{D}$, the evaluative function of the reported speech is made explicit 
by the concurrent laughter by the whole group in line 11 .

Anti-racism as common knowledge: the role of reported speech

One of the most commonly observed features of common-sense anti-racism across our data, and a phenomenon already noted in much of the data so far examined, is the use of reported speech. Reported speech or quotation has been categorised by Clark and Gerrig (1990) as a kind of 'demonstration': something that is linked to direct experience but mediated by a dramaturgical or role-taking function. Crucially, it is a selective or partial demonstration of some prior event, which may be specific in time or space, or which may be generic, habitual, typified or even hypothetical. Clark and Gerrig observe two main functions for the use of reported speech in talk: direct experience and detachment (1990: 792). Stokoe and Edwards (2007) have observed both these functions in the use of reported racist insults by complainants to neighbour mediation services or the police, where the reported quote of the racist offender both offers a kind of empirical robustness or 'factuality' (Myers 1999: 382) to their evidence (p.339; see also Buttny 2003: 106; Holt 1996), but also serves to dissociate the speaker from the insult (Clark and Gerrig 1990: 793; see also Buttny 2003: 106; Goffman 1974; Myers 1999: 376), rather offering up the insult to the listener as an indirect assessment of the original speaker's character and motives, commonly in 'complaint' narratives (Buttny, 2003: 106; Holt, 2000: 435-439; Stokoe and Edwards, 2007: 347). The role of reported 
speech in constructing evaluations or assessments is a crucial one in interaction. It has also been observed by Buttny (1997) in his study of racial discourse on a college campus, where he found that speakers would use reported speech overwhelmingly to criticise others, a function we observe most commonly in this study.

Across our data we find a number of realisations of reported speech which reveal a certain consistency of form and function. We have already seen an example of reported speech as a conveyance of direct experience or even direct emotion: '[.hhhh] $\uparrow \uparrow \underline{w h y}$ does he s- !', the sharp intake of breath followed by a high pitched, recreation of an imagined incredulous response by the speaker. However, most of our examples of reported speech have an ironic and critical function, serving to characterise the views and voice of usually a racist 'other' as an indirect form of critical commentary and conforms to Buttny's view that 'reported speech is relevantly tied to assessment' (1997: 477). Most of these examples use generalising particles as a way of typifying the speech as habitual, occurring over and over (e.g. 'they say things like I'm not racialist we're not racialist here'; 'people say oh you know the sort of classic they come to our country they should be like us' (itallics added). These are thus generic referents and hypothetical albeit familiar or 'prototypical' (Buttny, 2003: 105) speech reports of what a certain (often unidentified) group of people are likely to say. By juxtaposing the generalising particles with the reported speech, arguably common sense is being deployed as a way of characterising, stereotyping and stigmatising the racist view. 
In the next example, the speaker is characterising the racist views of her mum's Latvian cleaner who is talking about Polish migrants in the UK.

\section{EXTRACT G}

1 S6 my mum's cleaner is from Latvia (.) and even she's disgusted

2 by the ignorance of $£$ Polish opeople॰ and heh $\uparrow \uparrow £ y o u$ just think

3 that you've been here three $£$ four years $>$ or something $<($ (high

$4 \quad$ sing-song voice)) $\uparrow \uparrow$ and they all come ôver and they don’t

5 wo: $\uparrow \mathrm{rk}(0.4)$ there are $\uparrow \uparrow$ plenty of jobs ((normal voice)) (1.0)

6 and you just think $\uparrow$ okay (.) fair enough $(0.2)<$ which is a

7 shạ:me actually but ( )

8 S5 ye:ah.

9 S6 it seems a bit strange

(Edinburgh FB, Extra Time in Paradise)

The paralinguistic notes in the transcription itself ('high sing-song voice' and 'normal voice') suggests that the speaker adopts two distinct voices to make the separation between her views and the cleaner's views apparent, given the absence of a reporting verb. The speaker uses direct reported speech (lines 4-5) which lampoons the Latvian cleaner's generalising and arguably racist opinions regarding Polish migrants ${ }^{4}$. The ironic status of the report is evident by S6's use of a high 'sing-

\footnotetext{
${ }^{4}$ Ironically, in doing so, she makes a generalising judgement about Latvians.
} 
song' tone to convey the apparently reported speech (though she doesn't mimic an East European accent), a kind of delivery that has been described as having an 'annotative' (Clark and Gerrig 1990: 68), or 'marking' (Mitchell-Kernan, 1972) function which allows such things as prosody, gesture, and facial expression to offer an implicit commentary on the utterance. However, the absence of a reporting verb ('free direct speech' (Leech and Short, 1981: 22); 'zero-quotative' (Yule, Matnis and Hopkins, 1992)) also indexes the speaker's confidence in the shared and 'commonsensical' grounding of her reporting in an anti-racist interpretive context. However, even within the speaker's 'own' words, shades of the cleaner's voice are apparent. Prior to the reported speech, S6 refers to the 'ignorance' of Polish people (line 2), and although she is not directly quoting her cleaner here, it seems apparent from the otherwise anti-racist orientation of the rest of the turn, that the word 'ignorance' is a kind of quotation (arguably a form of free indirect discourse) and not one that S6 would normally deploy. Free indirect discourse is a form of indirect speech or thought without reporting clauses and usually constitutes a third person narration (with the attendant grammatical feature of the past tense) which nonetheless conveys the style, tone, views and perspective of the subject of the narration. It is commonly found in literary genres, and used in order to convey the 'colour' and expression of a particular character's view, often as a form of mimicry (see Gunn 2004 for a clear account). It occurs occasionally in these displays of 'common-sense anti-racism' as we will see in further examples. 
In the next example, the boundaries between reported speech and non-reported speech are less prosodically explicit:

\section{EXTRACT H}

1 S1 [and then you get it now excep]t it's about $\underline{\text { Mu:slims }}$

2 S2 [can see now how it goes there]

3 S2 yeh

4 S1 all Muslims are bad <anybody (0.2) brown skinned is a Muslim

5 whether they're Hindus or not doe:sn't matter

$6 \mathbf{S 2}$ yes

7 S1 they're just all lumped together as Mús:slims (0.4)and Muslim

$8 \quad$ equals ba:d

(Glasgow WI, Small Island)

In line 4, S1 voices a hearably racist view that 'all Muslims are bad <anybody (0.2) brown skinned is a Muslim', which we infer is a reported view by the way she then distances herself from it in her critical commentary in lines 5 and 7 . Nonetheless, shared, common-sense knowledge that such a view is meant ironically is also crucial to disambiguate it in the absence of any reporting verb or prosodic clues. We can compare this example to a very similar rhetorical move noted by Myers in a study of reported speech in focus group discussions, which he describes as free indirect discourse: 
2 your multinationals took in Bhopal . and look what happened there... with those poor people...

1 it didn't matter did it . cause they were only Indians

$2 \quad$ exactly ]

(Myers 1999: 337)

The connections between free indirect speech as a form of reporting and irony have been frequently documented, particularly in stylistic analyses (Gunn 2004), and the irony is not hard to detect here, particularly as the speakers in both extracts seem to be expressing an opinion opposite to that genuinely held by them. Both 'echoic mention' (Sperber and Wilson, 1981) and 'pretense' (Clark and Gerrig, 1984) theories of irony capture the verbatim and dramaturgical aspects of reported speech in the examples examined here. Shoaps (2010: 300) argues that 'irony has more in common with reported speech than it does with metaphor or negation' and both serve similar functions in making reference to shared norms and standards (often by contravening them). But like irony, reported speech has an evasive status, its words dissociated from the current speaker, and its intentions ultimately ambiguous. It is therefore an ideal mode of discourse to employ in interactional contexts where topics are liable to invoke disagreement or where (to quote Myers 1999) 'the views of speakers are not yet known'. We will return to some of these considerations in the paper's conclusions. 
The range of types of reported speech and frequent absence of explicit boundary markers within even a single turn is a useful marker of the intersubjective agreement presumed to exist between speaker and hearer, and a versatile means of establishing an anti-racist stance.

\section{EXTRACT I}

1 S5 I know it's I mean I kno:w (.) I've heard people going on that

2 they fought the Second World War (0.2) to make the country

3 British $>$ and all this $<$ and now there's all these $>$ Polish

$4 \quad$ people $<\uparrow$ oh but we're not against Polish people but it's all

$5 \quad(0.2) \uparrow \underline{c r i m i n a l s}$ that are $\downarrow$ coming and (.) see their people are

$6 \quad$ getting brai:nwashed $(0.4)$

7 S1 yeah [it's interesting

8 S5 ['cause it's the media

(Edinburgh PB White Teeth)

In this example, the boundaries between different forms of reported speech are even more ambiguous, particularly as some are not cued by explicit quotatives. The first bit of reported speech is introduced using a reporting verb 'going on' and begins as indirect speech, 'that they fought the Second World War', which is curtailed by the dismissive generaliser, 'and all this' (which is uttered with a more 'rushed' delivery signalled by the 'greater than' symbols in the transcript) before morphing imperceptibly 
into a form of free indirect speech 'and now there's all these $>$ Polish people $<$ '. In this way, the sentiment 'and now there's all these $>$ Polish people $<$ ' could be ambiguously ascribed to an anonymous group who hold the potentially racist views that the speaker is subtly lampooning. Again, the distinction between free indirect and free direct speech is ambiguous here ${ }^{5}$. The fact that these words are presumably not those of the speaker herself can only really be determined by other elements of the discourse context, such as the previously dismissive characterisation of the indirectly reported views of 'people going on' as well as by the free direct speech (direct reported speech without a reporting verb), which follows and which is arguably cued as such by the discourse marker, ‘ $\uparrow$ oh’: ‘ $\uparrow$ oh but we're not against Polish people’.

The absence of explicit markers of the boundaries between these different kinds of speech has been observed by Myers (1999: 396) as something which listeners are almost always competent to decode, even in the absence of clear cues, but whose interpretations can be recovered from subsequent turns. The shared knowledge that such a conversational strategy invokes is a clear example of common sense rhetoric: 'when speakers demonstrate only a snippet of an event, they tacitly assume that their addressees share the right background to interpret it in the same way they do' (Clark and Gerrig, 1990: 793). Such rhetorical moves also contribute to the establishment of intersubjectivity and affiliation in talk (Holt 2000: 451).

\footnotetext{
${ }^{5}$ Holt has remarked that the distinction between direct and indirect forms of reported speech are not always clear cut in interaction (Holt 1996: 243; 2000: 427)
} 
Our next example provides a clear illustration of how such 'embedded' quotations are processed by listeners and deployed to consolidate the anti-racist stance that is being jointly constructed across speaker turns. In this example (from Penzance in Cornwall), racism is attributed to 'the people' (and the definite article here implies a homogenous identity) in respectively Peterborough and London. Earlier in this section of talk, one speaker has described as 'shocking' the way black servicemen were treated after the war, but then another speaker notes that racism still persists in contemporary society:

\section{EXTRACT J}

1 SA but you know it it still happe:ns ah in Peter- I used to live

2 in Peterborough (0.2) ${ }^{\circ}$ and er॰ (.) the same thing happened (.)

3 ther- the people would say $(0.2)<\uparrow$ ' $\mathrm{f}$ you get one Pạ:ki $>(0.6)$

$4 \quad$ (0.4)they're all $\underline{\text { o:ver the place. }}$

5 SB yes

6 SA $\uparrow$ one Paki in the street and everybody starts moving on $\downarrow$ (.)

7 and $\uparrow$ this is (.) you know (.) ten fifteen years ago. (0.2) so

8 there's nothing (.) changed all that much=

9 SB =well it's happening right now because I've got people from

10 London on one side and people from London on the $\uparrow$ other side

11 and they've both (.) told me that they've moved here to get

12 away from the $\uparrow$ obla:cks॰ (0.2) and that's happening $\uparrow$ no: $:$ w

13 because this was last ye:ar when they moved in (0.2) so it's

$14 \quad$ still going on 
15 SC ooand the Cornish are moving to get away from the Londoners ${ }^{\circ}$

16 Group -s ys Heh heh heh heh

(Penzance, Small Island)

These constructions of apparently consistently racist dispositions are signalled by the habitual tense 'would say' which establishes the 'generic' and 'typified' forms of reported speech and their functions, and also by the use of the reviled 'hate' term: 'Paki'. These are used to shore up the contrastive, tacitly anti-racist perspective of the speakers, whilst simultaneously constructing a particular rural or provincial Cornish identity. SB's potentially ambiguous mention of 'the $\uparrow \stackrel{\uparrow}{\circ b l a: c k s}{ }^{\circ}$ ' in line 12 is arguably distanced from the speaker by its quieter yet emphatic and lengthened delivery combined with a 'surprised' tone, suggesting that this is more akin to reported speech rather than an expression SB would normally use or an ideology they would ordinarily subscribe to. An anti-racist interpretation can also be retrieved by the fact that SB's turn constitutes a 'second story' (Sacks 1992), with designed similarities to SA's story. This impression is then further consolidated by the final contribution from SC, arguably a 'third story', whose negative representation of the same racist 'Londoners' cited in the previous turn arguably helps to further disambiguate SB's mention of 'the blacks' in indirect speech, which is then confirmed by laughter from the whole group (and this is a good example of how anti-racist meanings, views and ideologies are collaboratively, sequentially and incrementally worked up in talk - the inverse of Condor's 2006 
discussion of how public prejudice is jointly accomplished in interaction). Despite the potential ambiguity of embedded reported speech, SC's response here suggests that she interprets SB's speech as reported and thus 'other'.

\section{Conclusions}

In this paper I have been interested to explore the forms and functions of common-sense anti-racism as it is performed and deployed in interaction and particularly through various forms of reported discourse. I have argued that the 'common' element of common sense is crucial to an understanding of the 'undeniable' status of anti-racism as it is accomplished by speakers, as a means of achieving consensus, signalling belonging of a particular kind of community, and managing potential disagreement. Common knowledge is less a 'reservoir of shared factual information which exists prior to, and is built up during, conversation' (Edwards, 1997: 117), but rather, the invocation of 'common knowledge' is a way of talking, of managing intersubjectivity, and achieving social goals such as presentation management, identity work, persuasion, accounting and blame.

However, I wish to return to my earlier observation that the "powerful norms of anti-racism' (Barnes et al 2001: 326), particularly in the kinds of liberal, educated contexts of the book club, might lead us to speculate as to why anti-racist stances are often achieved in talk using the same kind of rhetorical strategies one might associate 
with more contested or unpopular stances. In other words, common sense is usually used to naturalise ideological positions and is suggestive of an interactional need to counter a possible 'other view'. Myers, in his analysis of the functions of reported speech in focus group discussions, observed that its distancing properties often serve to 'mediat[e] disagreement' by 'giving participants a way of dealing with possible tensions and signalling intended frames' (1999: 389).

Whilst most of our examples of common-sense anti-racism seem to offer a robust alliance to a specific point of view, other examples are a little more ambiguous, and suggestive (as Myers noted) that anxieties continue to exist around discussions of race. As Mitchell et al suggest 'challenging racism is unlikely ever to be completely comfortable' (2011: 339) and similarly Condor concludes '[i]n practice, for ordinary social actors to openly challenge prejudiced talk as it arises incidentally in the flow of mundane conversation might seriously jeopardise their relationship with others' (2006: 16). In the following quote, the speaker uses a form of ellipsis ('enough said') which foreshortens his assessment (and removes potential reported talk).

\section{EXTRACT M}

1 S9 I mean $\underline{I}$ related to it (.) quite positively I I liked it but

2 for some of the reasons I touched on before it's set in a part

3 of London where my (0.2) > grandparents lived and my mother grew

$4 \quad$ up $<$ so I knew all those (0.2) areas I remember their reaction 
(Edinburgh, MBG, WhiteTeeth)

One reading of this is that ellipsis indexes shared knowledge, and the assumption that the listener will be able to supply the 'missing' token (i.e. that their reaction to immigrants is so objectionable as to be literally censored). Another reading might suggest that such an abrupt and censoring move operates to suppress discussion or the articulation of any alternative view, so that ellipsis in this instance sustains ambiguity around immigration and its evaluation. In other words, the 'common-sense' status of anti-racism, and its evasive, elliptical properties may, in some circumstances, operate to accommodate a range of unknowable views. The dilemma that arguably prompts the 'common-sense' forms of anti-racism is that either your interlocutors will need convincing that you are not racist, or that the interlocutors themselves cannot be trusted not to be racist. As Barnes et al observe ' $[t]$ he need for a strategy to avoid inferences of racism means that the risk of such an inference is genuine' (2001: 328). Similarly Whitehead observes in his study of race training group discussions that consequence of the expectation that others may be using such a framework to interpret their actions, and that others may hold them accountable for those actions on the basis of that framework. (2009: 339) 
In the broad communicative network that is 'race talk' we can see a continuum of common-sense discourse, from strategies of 'new racism', to defensive anticipation of the inference of racial common sense, to positive alignment to an anti-racist identity. All of these stances, frequently accomplished through the collaborative resources of sequential talk, reveal a sensitivity to the powerful stigma of racial prejudice that permeates almost all areas of contemporary social life.

\section{Funding}

This work was supported by an AHRC Diaspora, Migration and Identities large grant (2007-2010)

\section{Acknowledgements}

I am grateful to Andrew Smith, Elizabeth Stokoe, Joe Bray, Mark Nixon and an anonymous reviewer for their insightful input into the development of this article. Thanks must also go to Tessa Carroll for her work in collating some of the data.

\section{References}

Barker, M. (1981) The New Racism: Conservatives and the Ideology of the Tribe. London: Junction Books. 
Barnes, B., Palmary, I. and Durrheim, K. (2001) The denial of racism: The role of humor, personal experience, and self-censorship. Journal of Language and Social Psychology 20: 321-338.

Benwell, B., Procter, J. and Robinson, G. (2012) That may be where I come from, but that's not how I read: Diaspora, location and reading identities. In B. Benwell, J. Procter and G. Robinson (eds) Postcolonial Audiences: Readers, Viewers and Reception. London/NY: Routledge, 43-56.

Billig, M., Condor, S., Edwards, D., Gane, M., Middleton, D. and Radley, A.R. (1988) Ideological Dilemmas. London: Sage Publications.

Billig, M. (1996). Arguing and Thinking: a rhetorical approach to social psychology, revised edition. Cambridge: Cambridge University Press.

Billig, M. (2001) Humour and hatred: The racist jokes of the Ku Klux Klan, Discourse and Society 12 (3): 267-289.

Bonilla-Silva, E. and Forman, T. (2000) 'I am not a racist but...': Mapping white college students' racist ideology in the USA. Discourse and Society 11(1): 50-85.

Buttny, R. (1997) Reported speech in talking race on campus. Human Communication Research 23(4):477-506.

Buttny, R., \& Williams, P.L. (2000) Demanding respect: The uses of reported speech in discursive constructions of interracial contact. Discourse \& Society 11 (1): 109133. 
Buttny, R. (2003) Multiple voices in talking race: Pakeha reported speech in the discursive construction of the racial other. In H. Van den Berg, M. Wetherell, H.Houtkoop-Steenstra (eds) Analyzing race talk: Multidisciplinary perspectives on the research interview. New York, NY, US: Cambridge University Press, 103118.

Clark, H. H., \& Gerrig, R. J. (1990) Quotations as demonstrations. Language 66(4): 764-805.

Condor, S. (2006) Public prejudice as collaborative accomplishment: Towards a dialogic social psychology of racism. Journal of Community and Applied Social Psychology 16 (1): 1-18.

Edwards, D. (1994). Script formulations: A study of event descriptions in conversation. Journal of Language and Social Psychology. 13 (3): 211-247.

Edwards, D. (1997) Discourse and Cognition. London: Sage.

Fozdar, F. (2010) Duelling discourses, shared weapons: rhetorical techniques used to challenge racist arguments. Discourse and Society 19 (4): 529-547.

Garfinkel, H. (1956) Some sociological concepts and methods for psychiatrists. Psychiatric Research Reports 6: 181-198.

Garfinkel, H. (1967) Studies in Ethnomethodology. Englewood Cliffs, NJ: PrenticeHall. 
Gilroy, P. (1987) Two sides of anti-racism. In P. Gilroy (ed) There Ain't No Black in the Union Jack: The Cultural Politics of Race and Nation. London: Hutchinson, 114152.

Goffman, E. (1974) Frame Analysis. New York: Harper and Row.

Gunn, D. (2004) Free indirect discourse and narrative authority in Emma Narrative 12(1): 35-54.

Holt, E. (1996) Reporting on talk: The use of direct reported speech in conversation. Research on Language and Social Interaction 29(3): 219-245.

Holt, E. (2000) Reporting and reacting: Concurrent responses to reported speech. Research on Language and Social Interaction. 33(4): 425-454.

Jefferson, G. (1990) List-construction as a task and a resource. In George Psathas, (ed) Interaction Competence. Washington, D.C.: University Press of America, 63-92. Leech, G. and Short, M. (1981) Style in Fiction. London: Longman.

Long, E. (2003) Book Clubs: Women and the Uses of Reading in Everyday Life. University of Chicago Press.

McHoul, A. and Watson, D.R. (1984) Two axes for the analysis of 'commonsense' and 'formal' geographical knowledge in classroom talk, British Journal of the Sociology of Education 5: 281-302. 
Mitchell-Kernan, C. (1972) Signifying and marking: Two Afro-American speech acts. In J. Gumperz and D. Hymes (eds) Directions in Sociolinguistics: The Ethnography of Communication. Oxford: Blackwell.

Mitchell, M., Every, D. and Ranzijn, R. (2011) Everyday antiracism in interpersonal contexts: Constraining and facilitating factors for 'speaking up' against racism. Journal of Community and Applied Social Psychology 21(4): 329-341.

Myers, Greg (1999) Functions of reported speech in group discussions. Applied Linguistics, 20 (3): 376-401.

New Shorter Oxford English Dictionary (1993) (Fourth Edition). Oxford: OUP.

Oxford English Dictionary online, http://www.oed.com/ accessed 6/9/2011.

Pollner, M. (1987) Mundane Reason: Reality in Everyday Life and Sociological Discourse. Cambridge: Cambridge University Press.

Pomerantz, A. (1986) Extreme case formulations: A way of legitimizing claims. Human Studies, 9 (2-3): 219-229.

Rapley, M. (1998) 'Just an ordinary Australian': Self-categorisation and the discursive construction of facticity in 'new racist' political rhetoric. British Journal of Social Psychology 37(3): 325344.

Sacks, H. (1992) Lectures on Conversation. Oxford: Blackwell.

Schiffrin, D. (1987) Discourse Markers. Cambridge: CUP. 
Shoaps, R. (2010) 'Moral irony': Modal particles, moral persons and indirect stancetaking in Sakapultek discourse. Pragmatics 17(2): 297-335.

Sperber, D. and Wilson, D. (1981) Irony and the use-mention distinction. In P. Cole (ed) Radical Pragmatics. Academic Press, New York, 295-318.

Stokoe, E. (2010) Gender, conversation analysis, and the anatomy of membership categorization practices. Social and Personality Psychology Compass 4(7): 428438.

Stokoe, E. (2012, in press) 'You know how men are': Description, categorization and the anatomy of a categorial practice. Gender and Language.

Stokoe, E., \& Edwards, D. (2007) 'Black this, black that': Racial insults and reported speech in neighbour complaints and police interrogations. Discourse \& Society, 18(3): 337-372.

Van den Berg, H., Wetherell, M., Houtkoop-Steenstra, H. (eds) (2003) Analyzing race talk: Multidisciplinary perspectives on the research interview. New York, NY, US: Cambridge University Press.

Van Dijk (1987) Communicating Racism: Ethnic Prejudice in Thought and Talk. London: Sage.

Van Dijk, (1991) Racism and the Press. London: Routledge.

Van Dijk, (1992) Discourse and the denial of racism. Discourse and Society 3(1): 87118. 
Verkuyten, M., De Jong, W., Masson, K. (2002) Similarities in anti-racist and racist discourse: Dutch local residents talking about ethnic minorities. In J. Giltrow (ed) Academic Reading: Reading and Writing in the Disciplines. Broadview Press, 434-452.

Wetherell, M., Potter, J., (1992) Mapping the Language of Racism: Discourse and the Legitimation of Exploitation. Hemel Hempstead: Harvester Wheatsheaf.

Whitehead, K. (2009) 'Categorizing the categorizer': The management of racial common sense in interaction. Social Psychology Quarterly 72 (4): 325-342.

Yule, G., Mathis, T. and Hopkins, M. (1992) On reporting what was said. ELT Journal 46(3): 245-251. 